\title{
地理学評論 Ser. A の現状と課題
}

\author{
杉 浦 芳 夫* \\ Current Status and Problems of Geographical \\ Review of Japan, Ser. A
}

Yoshio SUGIURA*

I. はじめに

地理学評論 Ser. A（以下地理評と略す）は, 会 員約 3,200 人を擁する日本最大の地理学関連学会 の日本地理学会が刊行する和文機関誌である ${ }^{1)}$ 。 地理評は, 日本地理学会が創立した大正 14 （1925）年に創刊し，大戦末期の休刊を除き，月 刊誌として今日まで刊行され続け, 現在 72 巻を 数えるに至っている。日本の地理学の専門学術雑 誌としては唯一戦前から刊行されているものであ り, 日本における地理学の制度化（科学全体ない しは個別学問の専門職業化）に少なからぬ貢献を なしてきた。その意味では, 地理評の歴史は日本 のアカデミックな地理学の歴史そのものといって もよいであろう。

現在, 毎月約 3,500 部が会員と内外の研究機関 へ配布・交換寄贈され, 約 700 部が大学 ·図書館 も含めた一般購読者に書店を通して販売されてい る。その刊行にかかる経費は, 1998 年度の場合, B5 版サイズの本文 924 頁で, Geographical Review of Japan, Ser. B と合わせ約 1,800 万円 (文部省から支給される出版助成金を含む), 日本 地理学会の年間予算支出額の $40 \%$ 弱を占めてい $る^{2)}$ 。

本稿は, 現在編集委員長の任にある筆者の私見 を交えつつ, 近年の投稿・掲載状況を踏まえて, 地理評の現状と問題点・課題について報告するこ
とを目的とするものである。地理評の簡単な歴史 や戦前の掲載論文の傾向については, 矢澤 (1975, pp. 71-80)，立岡（1987）によって報告されたこ とはあったが, その現状や課題について論文の形 でまとめられたことはこれまでなかっだ)。

\section{II. 原稿の投稿から掲載まで}

地理評の原稿の種類は, 論説, 総説, 短報, 資 料, 討論, 書評, フォーラムからなり (表 1 ), 特 別講演や分量の多いシンポジウム報告が論文体裁 で掲載されることもあった。このうち，庶務専門 委員会で採否を決定するフォーラムを除き，他の 原稿は編集専門委員会で掲載の可否を決定してい る（編集専門委員会での投稿原稿の審査方法につ いては，次章で別途詳述する）。なお，これ以外 に西暦奇数年度には会長講演の論文も掲載されて いる。各種原稿の長さの上限は表 1 に示すように 決められており, その上限を越えると, 規定の超 過頁経費を著者が負担しなくてはならない。

地理評には, 毎号, 論文 (論説, 総説, 短報, 資料, 討論) は $2 \sim 4$ 編掲載され, 日本地理学会 がニューズレターを発行していないため，それ以 外に, 学界消息, 教官公募, 他学会・研究集会開 催案内, 研究奨励金募集等の記事も掲載されてい る。また，毎年 6 月号と翌年 1 月号には，それぞ れ春季学術大会開催時の評議員会・総会報告記事, 秋季学術大会開催時の評議員会報告記事が掲載さ

* 東京都立大学大学院理学研究科地理学教室 [地理学評論 Ser. A 編集委員長]

* Department of Geography, Tokyo Metropolitan University (Chief Editor, Geographical Review of Japan, Ser. A ] 
表 1 原稿の種類.

\begin{tabular}{|c|c|}
\hline 類 & 内 \\
\hline 論 説 & $\begin{array}{l}\text { その長短にかかわらず, オリジナルな研究成果をまとめたもの. 本会の } \\
\text { 学術大会などの研究集会で発表し, 討論を経たものであることを原則と } \\
\text { する. 長さは16頁以内で, 摘要, 英文要旨, キーワードを付ける. }\end{array}$ \\
\hline 説 & $\begin{array}{l}\text { ある主題に関する研究成果を分析・検討し, 研究史, 研究の現状, 将来 } \\
\text { への展望などについてまとめたもの. 長さは } 16 \text { 頁以内で, 摘要, 英文要 } \\
\text { 旨, キーワードを付ける. }\end{array}$ \\
\hline 短 報 & $\begin{array}{l}\text { 論説の内容となり得る情報を含む調査研究成果の速報, 総説の内容とな } \\
\text { り得る情報を含む研究動向・研究展望の紹介や報告, 新しい研究手法の } \\
\text { 提案など. } 8 \text { 頁以内で, 摘要, 英文要旨, キーワードを付ける. }\end{array}$ \\
\hline 資 料 & $\begin{array}{l}\text { 地理学に関係のある調査, 記録, 統計などに基づいて, 資料的に価值の } \\
\text { ある情報をまとめたもの. 長さは } 8 \text { 頁以内. }\end{array}$ \\
\hline 討 論 & $\begin{array}{l}\text { 本会の機関誌に掲載された論説, 短報などに対する批判·質問とそれに } \\
\text { 対する著者からの反論・回答. 長さは } 8 \text { 頁以内. }\end{array}$ \\
\hline 書 評 & 地理学に関係のある文献に関する批評や紹介. 長さは 2 頁以内. \\
\hline フォーラム & 地理学の振興などに関する意見‧要望など．長さは 2 頁以内. \\
\hline
\end{tabular}

刷り上がり 1 頁には 23 字 $\times 72$ 行分の文字数が入る.

れる。さらに，7月号ないしは 8 月号には，地理 学関連教室に前年度提出された修士論文・博士論 文の一覧が掲載される。

地理評へ投稿できる人は, 編集専門委員会が特 別に依頼した人を除き, 会員（正会員, 学生会員, 名誉会員）に限定されている（連名の場合は筆頭 著者が会員でなくてはならない)。とりわけ論説 の投稿に際しては, 事前に口頭発表し, 十分な討 論を経たものであることを前提としている。

投稿原稿は，学会指定の原稿用紙を用いた手書 き原稿も認められているが，現在ではほぼ100\% がワードプロセッサーで作成されたハードコピー 原稿である。電子メイルでの投稿は現在のところ 認めていない。詳しい投稿規定・執筆要領は, 2 年ごとに発行される『日本地理学会会員名簿』の 後に 8 頁にわたって掲載されており，その発行に 合わせ，編集専門委員会は投稿規定・執筆要領の 見直しを 2 年ごとに行なっている。

編集専門委員会での審査を経て受理が決定した 原稿は, 担当委員以外の別の編集専門委員が, 言 葉遣いや文献リスト等の最終チェックを行ない,
最後の修正を著者に打願いしている。著者には修 正が済み次第，ハードコピー原稿とフロッピーディ スク入力済み原稿を提出してもらう。そのまま印 刷用の版下となる図もこの時点で提出してもらう ことになっている。

原稿は印刷所にフロッピーディスクで入稿し， 初校のゲラ刷りは掲載月の 1 ケ月前にできあがり, 著者のほか, 学会専任の編集書記, 担当編集専門 委員, 編集委員長が校正に当たる。最終校の 2 校 のゲラ刷りは編集書記のみが校正し, 必要に応じ 編集委員長も再度目を通すことがある。

なお, 最新号の地理評の発刊と同時に, 掲載論 文の著者名・論文タイトルと, 学会消息等の会員 向け記事は, 日本地理学会のホームページ (URL は, http://nacsis.ac.jp/ajg/index.html）に掲載 している。さらに，論文検索に供する目的で, 1988 年以降掲載した論文の著者名・論文タイトル もホームページに掲載してある。これは, 1987 年 の巻まで 10 年分ごとに刊行されていた冊子体の 総索引に代わるものであるとされている。ただし， 冊子体のように人名 ·地域 ·事項別に分類されて 
いないので，利用者は一旦ダウンロードして検索 用に独自加工しなければ使えない。

\section{III. 査読システム}

原稿の採否を決定する編集専門委員会は，いず れも 2 年任期の委員長以下 10 数名の編集専門委 員からなり, 編集の実務は編集書記が担当してい る。委員長は, 会員によって直接選挙された評議 員の互選で選ばれた常任委員長が，同様の互選に より選ばれた 8 名の常任委員の中から指名するこ とで決定される。編集委員長は, 研究分野のバラ ンスと在職機関を考慮して会員の中から編集専門 委員を決めている。

8 月を除き毎月開催される編集会議では, 新規 投稿原稿ごとに，適任と思われる担当委員を決め た上で, 複数名の会員に外部査読を依頼している。 外部查読者の決定に当たっては，研究分野的に投 稿原稿の評価を的確にできる人であることはもち ろんのこと，投稿者と職場を共にする人，投稿者 と年齢があまり離れていない同じ出身大学関係者 は避けている。会員の中に適当な外部査読者がい ない場合には, 非会員の方に些少の謝礼を差し上 げお願いしている。

論文審査に際しては，査読者が自由な意見を表 明できるよう投稿者に対して担当委員と外部査読 者の氏名を伏せるだけでなく，後述のように 1998 年度からは公平さを期すため, 外部査読者にも投 稿者の氏名が一切わからないようにしてある。た だし，毎年 12 月号には，査読の労に対する謝意 を表わす意味で，外部査読者を務めていただいた 方々の氏名を一括揭載している。

外部查読者から査読結果が戻されると, 編集会 議において, 担当委員と外部査読者の所見を参考 にして，最終的な原稿の採否を出席委員全員の合 議で決定している。修正の必要がある場合には， 担当委員が審議結果を文書にまとめ, 本文中にも コメントが直接記してある原稿ともども学会事務 局経由で速やかに著者に送り返すことになってい る。

著者は編集専門委員会からの修正要求に対し, 妥当と思う指摘に関しては修正し，受け入れがた
いと思う点に関してはその理由を記した文書を添 付し, 前回投稿原稿とともに修正原稿を再投稿す ることができる。再投稿原稿に対し, 提案した方 向で書き改められていれば以後担当委員のみで審 査するが，内容が大きく変更されている場合には， 外部査読者に再審査を依頼することもある。こう した審査プロセスが再々投稿以降の原稿に対して も繰り返され, 最終的に問題がなくなったとき原 稿は受理される。この受理日は, 原稿の受付日と もども掲載された論文の末尾に明記されている。

投稿原稿はできるだけ掲載する方向で考えると いうのが地理評の基本的な審査方針であり，とく に将来の学界を背負って立つ大学院生クラスの若 手研究者の投稿原稿に対してこの方針が貫かれて いる。原稿の受付日に 30 歳未満の投稿者, 30 歳 以上ではあっても原稿の受理日に学生会員である 投稿者に別刷を 100 部まで無料としている点, 毎 年, 満 35 歳未満の著者の掲載論文の中から, 自 然地理, 人文地理各 1 編の優れた論文に対し, 研 究奨励賞 (賞状と賞金) を授与している点等, 日 本地理学会は若手研究者に対して論文審査以外に も一定の配慮をしている。

なお，通常号以外に，ある月の号を特集号にあ てることがある。この 5 年間では, 「阪神・淡路 大震災」「地理教育」「国土開発と地域政策」の三 つの特集号が刊行されている。このうち阪神 · 淡 路大震災特集号については編集専門委員会が投稿 者を募ったものであるが, 普通は日本地理学会内 の研究・作業グループ4)が大会シンポジウムで発 表した研究成果をまとめる形で特集号が組まれる。 その刊行に当たっては編集専門委員会とは別に特 集号編集委員会が組織され, 論文審査は通常号に ほほ準じて行なわれる。ちなみに, 1999 年 9 月号 としては「中国の土地利用・被覆変化と食糧問題」 特集号が, 2000 年 4 月号としては「日本地理学会 75 年史」特集号が刊行の予定になっている。

\section{IV. 投稿・掲載状況からみた地理評の 問題と課題}

地理評の在り方については, 日本地理学会の企 画専門委員会を中心に, これまで折にふれ議論さ 
表 2 論文の種類・分野別にみた掲載論文数.

\begin{tabular}{|c|c|c|c|}
\hline & 合計 & 自然地理 & 人文地理 \\
\hline 論説 & $\begin{array}{l}102(68.0 \%) \\
(100.0 \%)\end{array}$ & $\begin{array}{l}34 \quad(59.6 \%) \\
(33.3 \%)\end{array}$ & $\begin{array}{l}68(73.1 \%) \\
(66.7 \%)\end{array}$ \\
\hline 短報 & $\begin{array}{l}43 \quad(28.7 \%) \\
(100.0 \%)\end{array}$ & $\begin{array}{l}23 \quad(40.4 \%) \\
(53.5 \%)\end{array}$ & $\begin{array}{l}20(21.5 \%) \\
(46.5 \%)\end{array}$ \\
\hline 総説 * & $\begin{array}{l}3(2.0 \%) \\
(100.0 \%)\end{array}$ & 0 & $\begin{array}{l}3(3.2 \%) \\
(100.0 \%)\end{array}$ \\
\hline 資料 & $\begin{array}{l}2(1.3 \%) \\
(100.0 \%)\end{array}$ & 0 & $\begin{array}{l}2(2.2 \%) \\
(100.0 \%)\end{array}$ \\
\hline 合計 & $\begin{array}{l}150(100.0 \%) \\
(100.0 \%)\end{array}$ & $\begin{array}{l}57(100.0 \%) \\
(38.0 \%)\end{array}$ & $\begin{array}{l}93(100.0 \%) \\
(62.0 \%)\end{array}$ \\
\hline
\end{tabular}

*展望を含んでいる。なお, 自然地理分野の学説史 論文も人文地理に含めてある.

れてきた。そして，1996１997 年度の常任委員会 は学会の法人化に向けての活動の一環として, 現 行の地理評の改組についての具体案を示した。本 稿では, そこでの議論も踏まえつつ, 近年の投稿・ 掲載状況に基づき, 地理評の問題と課題について 考えてみることにする ${ }^{5)}$ 。

本稿が対象とする近年の論文とは, 最近 5 年間 のものであり, 地理評の 1995 年 1 月号 1999 年 8 月号の, 前記三つの特集号を除く, 全 53 冊の地 理評に通常の査読を経て掲載された 150 論文 ${ }^{6)}$ さしている。150論文の種類の内訳は表 2 に示す とおりであり， 3 分の 2 が論説で占められている。 総説についてのみ付言すれば, 1981 年 12 月に総 説・展望（現在の総説）のカテゴリーが新設され， 学会役員へのアンケートでも展望 (総説) 論文掲 載の要望は多い（日本地理学会企画専門委員会, 1993, p. 816）が，投稿者が殆どみられないのが 実状である。少なくとも人文地理の分野に限れば, 雑誌「人文地理」が以前から展望論文を毎号掲載 し，同誌のセールスポイントになっているため， 人文地理の分野の展望論文はそちらへ流れてしま うのかもしれない。

\section{1）投稿数と受理までの期間}

この 5 年間の 51 回の編集会議（1995 年 1 月〜 1999 年 7 月）にかけられた新規投稿原稿の数から,

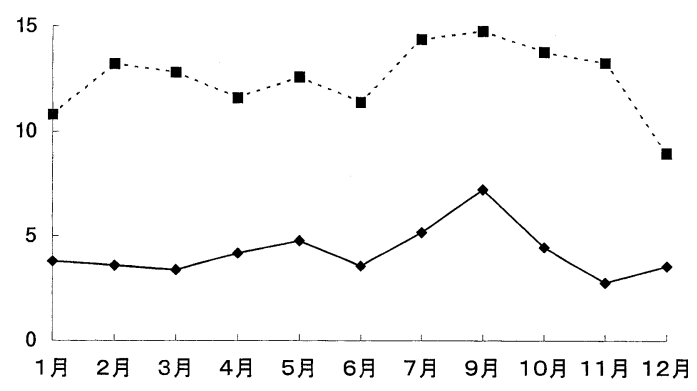

図 1 月別の平均投稿数 (実線). 平均審査原稿数 (破線).

1〜7月は 1995〜1999 年の平均，9１2 月は 1995〜 1998 年の平均である. 8 月分の実績が示されていな いのは，同月に編集会議が開催されていないからで ある。

月別の平均投稿数の推移（図 1) をみると，夏休 み明けの 9 月の編集会議に向けての投稿が 7.3 編 と最も多い。投稿者が夏休みを利用して原稿を完 成させる傾向が現われているように見受けられる かもしれないが，8月に編集会議が開かれず，9 月に 2 ケ月分まとめて計上してあるためにこのよ うな結果となっている。この点を考慮すれば，月 別平均でみる限り, 投稿数は 4 編前後でほぼ定 しているといえよう。全体を通しての平均も月 4.3 編であるが， 51 ケ月を個別にみていくと，最 高で 9 編（4回），最低で 0 編（1回）とかなり変 動があるのも事実である。初回投稿論文だけでな く, 再投稿以降の論文の審査数も加えた月別平均 審査原稿数からみると，7１0月の夏休みをはさ む前後でやや多く，12１月の冬休みをはさむ前 後で少なくなっている（図1参照）。委員会全体 としての査読の仕事には多少季節性がみられるよ うである。

編集専門委員会にとって毎月同じ数の投稿があ ることは望ましいことであるが，恐らくここで問 題となるのは, 月平均 4.3 編という投稿数が, 会 員数 3,000 人を越える学会の月刊誌としてみた場 合，多いか少ないかという点であろう。一定数の 投稿が続くことを前提に，受理が決定してから初 校が出るまでにかかる期間は約 2 ケ月，初校から 掲載までにかかる期間が 1 ケ月，合わせて 3 ケ月 で受理原稿が掲載されることを標準日程として， 
表 3 受理までの期間.

\begin{tabular}{c|cc}
\hline 月数 & \multicolumn{2}{|c}{ 頻度 } \\
\hline $1 \sim 3$ & 18 & $(12.0 \%)$ \\
$4 \sim 6$ & 64 & $(42.7 \%)$ \\
$7 \sim 9$ & 28 & $(18.7 \%)$ \\
$10 \sim 12$ & 21 & $(14.0 \%)$ \\
$13 \sim 15$ & 12 & $(8.0 \%)$ \\
$16 \sim 18$ & 3 & $(2.0 \%)$ \\
$19 \sim 21$ & 2 & $(1.3 \%)$ \\
$22 \sim 24$ & 1 & $(0.7 \%)$ \\
$25 \sim 27$ & 1 & $(0.7 \%)$ \\
\hline 合計 & $150(100.0 \%)^{*}$ \\
\hline
\end{tabular}

*丸めの誤差により合計は $100 \%$ にならない.

編集が進められる。実際に受理から掲載に至るま での平均月数は 3.7 ケ西ある。当然のことなが ら, 受理した原稿数が多ければ掲載までにかかる 時間は長くなり，この 5 年間では最高で 8 ケ月後 に掲載された論文もあった。しかし，これは特集 号が二つあまり間をおかずに発行されたことの影 響であり，殆どは3〜4 ケ月で印刷に付されてい る。

投稿者の側からすると，原稿が早く活字化され ることはうれしいに違いない。しかし，受理から 掲載までが $3 〜 4$ ケ月ということは, 編集の側か らすると手持ち原稿がないまま「自転車操業的」 刊行を続けているといえなくもない。というのも， 毎月の平均の受理数は 2.9 編であり, この原稿数 では 1 号分を埋めるのが苦しい場合もあるからで ある。以上のことを勘案すると, 地理評は実は慢 性的な原稿不足にあるのではないかというのが私 の結論である。

毎月の編集会議における平均の審査原稿数は 12.5 編で, この数自体は決して少ないとはいえな い。しかし, そこには再投稿, 再々投稿の原稿も 含まれているので,「自転車操業的」刊行の根底 には, 単なる原稿不足以上に, 投稿原稿の完成度 の低さの問題があるように思われる。この点は, 実は 10 年来各期の編集専門委員会で指摘され続 けていることでもある7)。受理までに要した月数 の平均は 7.5 ケ月であり, その頻度分布をみると
表 4 著者の年齢の頻度分布.

\begin{tabular}{c|c}
\hline 年齢 & \multicolumn{2}{|c}{ 頻度 } \\
\hline$\sim 25$ & $7 \quad(4.7 \%)$ \\
$26 \sim 30$ & $60(40.0 \%)$ \\
$31 \sim 35$ & $25 \quad(16.7 \%)$ \\
$36 \sim 40$ & $18(12.0 \%)$ \\
$41 \sim 45$ & $16(10.7 \%)$ \\
$46 \sim 50$ & $9(6.0 \%)$ \\
$51 \sim 55$ & $8 \quad(5.3 \%)$ \\
$56 \sim 60$ & $6(4.0 \%)$ \\
$61 \sim 65$ & 0 \\
$66 \sim 70$ & $1 \quad(0.7 \%)$ \\
\hline 合計 & $150(100.0 \%) *$ \\
\hline
\end{tabular}

*丸めの誤差により合計は $100 \%$ にならない.

最頻值は 4〜6 ケ月の約 $40 \%$ で，半年以内に $50 \%$ 強の原稿が受理されている(表3)。しかし, 受理 までに 10 ケ以上を要するもの，つまり投稿か ら掲載までに 1 年以上かかるものも 4 分の 1 ある。 最近 2 年間に限れば，受理までに要した月数の平 均はさらに2ヶ月長くなり 9 ケを超えている。 著者との間の 1 回の往復で掲載される原稿は少な く, 殆どが最低 2 回往復して受理に至っている。 4 回以上往復する原稿もまれではない。どうみて も完成度の高い原稿が多いとはいえないのである。

他方, 過去 5 年間に却下した原稿は 15 編, 年 平均 3 編である。その間の投稿原稿 219 編に比し て，1割にも満たない数である。もちろん，再投 稿，再々投稿されないままの原稿もあるので，実 質的な却下原稿はもっと多いのかもしれない。い ずれにしても，地理評の評価を高めるためには， より多くの質の良い原稿の投稿が期待されるので ある。

\section{2) 著者の年齢}

原稿の出来, 不出来は内容の問題もあるが, 論 文を書き慣れているかどうかということとも関係 しているであろう。この点は投稿者の年齢と関係 する問題でもある。掲載論文の著者（連名の場合 は筆頭著者のみ）の平均年齢は 35.5 歳, 1996 年 以降次第に若くなってきており，1996 年と 1999 年の平均年齢の差は約 2 歳である。著者の年齢の 


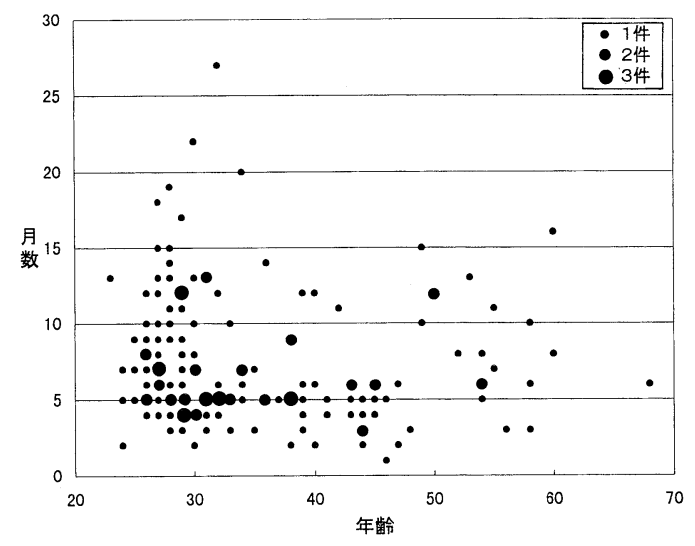

図 2 著者の年齢と受理までの月数の関係.

頻度分布をみると，最頻值は 26〜30 歳の 40\%で あり，35 歳以下の若手が約 $60 \%$ を占めている (表 4)。少し前のものではあるが, 1993 年時点の 日本地理学会会員の 10 歳ごとの年齢構成比をみ ると, 50 歳未満の会員数を合計してはじめて 60 \%を越える（原山，1996，p. 264）ので, 会員の 年齢構成と照らし合わせても, 若手の投稿数は突 出している。しかし， 31３5 歳で著者数は急減し, 以後年齢を重ねるにつれて, 割合は減り続ける。 この事実は, 大学院生クラスの若手が業績を上げ るために地理評へ投稿するが，一旦就職してしま うと，職務が多忙になることもあって，投稿しな くなる可能性が高いことを示唆している。それを 逆にみると, 地理評が若手の地理学界への登竜門 の役割を果たしていることの証左ともいえよう。

投稿経験の乏しい若手の投稿数が多いというこ とが，受理までに要する期間を長くしていること の一因ではないかと考えられるので, 著者の受理 時点での年齢と原稿が受理されるまでの月数との 関係を調べてみた（図 2)。とりたてて明瞭な関係 があるとはいえないものの, 年齢が若いほど受理 されるまでの月数には大きなバラツキがあること は明らかである。すなわち, 30 歳代の半ばより上 の年齢層は受理までの月数がほぼ 15 ケ月以内に 収まっているのに対し，30歳代半ばより下の年齢 層では 15 ケ月を越えるものも散見されるのであ る。もっとも，次のようなことも考えられるので，
中堅以上になると受理までの期間が比較的短くな る傾向にあることの理由を，投稿経験の豊富さだ けに求めることはできないであろう。決してあっ てはならないことではあるが，ある分野で「名を なしている」投稿者の原稿に対する査読者の評価 が甘くなることはないのであろうか。あるいは逆 に「無名の新人」の投稿原稿の評価が辛くなるこ とはないのであろうか。こうしたことを避けるた めに, 今期（1998 年〜1999 年度）の編集専門委 員会から, 外部査読者に対し投稿者の氏名を伏せ るようにしている。

受理を長引かせる原因は, 論文構成のまずさや 論旨の矛盾は論外として, 本文での引用と文献表 の対応の不備, 執筆要領に合致しない文献表, 縮 小率を考慮していない図, 局所的な修正にのみ目 を奪われたことによる論旨の混乱，本文と図表と の間で一致しない数字等が，やはり 10 年来編集 専門委員会から指摘され続けている ${ }^{8)}$ 。容易な修 正を可能とするワードプロセッサーや作図ソフト の普及が，「作品」としての論文を仕上げること への執着心を投稿者から奪い去っているというの は言い過ぎであろうか。そうした傾向がとりわけ 論文執筆経験の浅い投稿者に顕著であることを， 投稿者だけでなく指導に当たられる関係者に改め て申し添えておきたい。

一方，受理が長引く原因を投稿者の側だけに帰 すことが非常に片手落ちであることも十分承知し ているつもりである。編集専門委員会としては,

審査結果の速やかな著者への通知を旨としている ものの，担当委員や外部査読者のやむを得ない事 情により審査が遅れることがあるのもまた事実で ある。その際には逐一投稿者へ現状報告を行なっ ている。過去に審査の遅れが投稿者に迷惑をかけ たことがあったので，編集専門委員会はそうした ことが起こらないように迅速な審査をできる限り 心がけるようにしている。

\section{3）自然地理と人文地理の掲載論文数}

やはり以前から編集専門委員会が投稿傾向につ いて指摘し続けていることとして, 自然地理論文 の少なさがある ${ }^{9)}$ 。この 5 年間の自然地理と人文 地理の揭載論文数を比較してみると, ほぼ 4 対 6 
表 5 論文の種類・分野別にみた受理までの期間 (単位 : 月数).

\begin{tabular}{|c|c|c|c|c|c|c|}
\hline & \multicolumn{2}{|c|}{ 全体 } & \multicolumn{2}{|c|}{ 自然地理 } & \multicolumn{2}{|c|}{ 人文地理 } \\
\hline & 平均 & 標準偏差 & 平均 & 標準偏差 & 平均 & 標準偏差 \\
\hline 論説 & 7.6 & 4.0 & 7.1 & 3.7 & 7.9 & 4.2 \\
\hline 短報 & 7.1 & 4.8 & 7.3 & 3.8 & 6.8 & 5.7 \\
\hline
\end{tabular}

の割合 (表 2 参照) であり, 人文地理論文が自然 地理論文を数の上で上回っていることがわかる。 さらに掲載数の多い論説と短報だけに分類してみ ると (表 2 参照), 論説では自然地理と人文地理 の割合が 1 対 2 となり,この傾向に一層拍車がか かる。それに対し, 短報は両者の割合がほぼ同じ である。

確かに論説を中心にして人文地理論文が多いこ とはわかるが,これをもって自然地理研究者は地 理評へ投稿する意欲が少ないと言い切ってよいで あろうか。例えば, 1993 年時点における日本地理 学会会員の 54 の専門・関心分野の中で, 自然地 理の分野と思われる 14 分野を, 自らの専門・関 心分野の第 1 位にあげた会員の割合は $37.3 \%$, 第 1 位から第 3 位までにあげた会員の割合は $32.5 \%$ であり ${ }^{10)}$, 自然地理を専門とするか, あるいは関 心を持つ会員の割合はおおよそ30〜 $40 \%$ と推測さ れる。この層が地理評へ自然地理論文を投稿する 可能性のある母集団と仮定すれば，その割合は前 記の掲載された自然地理論文の割合にほぼ一致し ているのである。地理学は自然地理と人文地理が 同じウェイトを持って成立していると考える限り は, 確かに自然地理論文の掲載数は少ない。しか し, 会員の専門・関心分野構成比を考慮すれば, 自然地理と人文地理の論文掲載数は相拮抗してい るのである。

したがって, 問題とすべきことは, 自然地理と 人文地理の論文掲載数の表面上の違いではなく, 両者の掲載論文の種類の違いであろう。自然地理 論文はなぜ相対的に短報が多いのであろうか（表 2 参照)。これには二つのことが関係しているよう に思われる。第一に, データの提示それ自体が意 味を持つ場合がある自然地理学の分野では, とり
わけ速報性が重視されるため, 論文としてまとめ やすい短報が指向されることが多いからである。 実際に，1996１997年度の編集専門委員会は，論 説で投稿しても審査の時間がかかると思われる内 容の原稿に対しては, 短報で再投稿することを積 極的に勧めてきた ${ }^{11)}$ 。しかし，論説・短報別に受 理までにかかった平均の期間を調べてみると, 意 外にも, 自然地理の場合, 短報と論説の受理まで の月数はほぼ同じであり,むしろ人文地理の方が 短報は 1 ケ月ほど論説より受理が早くなっている （表 5)。少なくとも自然地理に関しては，原稿の 掲載のされやすさに対して投稿者が持っていると 思われるイメージと現実との間には乘離があるよ うである。

自然地理の短報の多さを決定づける 2 番目の原 因としては，より中味の濃い論説的内容の原稿は, 自然地理関連の他の専門学術雑誌へ投稿されてい るのではないかということが考えられる。国内の 学術雑誌に限っても, 地形学関係では「第四紀研 究」「地形」, 気候学関係では「気象集誌」(英文), 「天気」, 水文学関係では「日本水文科学会誌」 「水文・水資源学会誌」, 植生地理学関係では「日 本生態学会誌」「日本林学会誌」等がある。それ に比べると，人文地理の（特定分野の）論文のみ を掲載する学術雑誌としては, 「人文地理」「経済 地理学年報」「歴史地理学」の 3 誌しかない。こ うした投稿誌の選択肢の多萓が, 地理評における 自然地理の論説の少なさと人文地理の論説の多さ に関係していると考えられるのである。自然地理 の論説の少なさは, やがては自然地理研究者の地 理評離れ，ひいては日本地理学会離れにつながり， 最終的には日本地理学会の会員数の動向にも影響 を与えかねないのである。 
表 6 日本地理学会会員ならびに著者の職業構成(1999年 3 月 20 日現在).

\begin{tabular}{|c|c|c|c|}
\hline & 会員 ${ }^{*}$ & \multicolumn{2}{|r|}{ 著者 } \\
\hline 大学・短大·高専教員（含非常勤） & $1,067 \quad(33.4 \%)$ & 75 & $(50.0 \%)$ \\
\hline 小·中·高校等教員（含非常勤） & $741 \quad(23.2 \%)$ & 3 & $(2.0 \%)$ \\
\hline 民間企業·官公庁等勤務（含非常勤） & $640 \quad(20.0 \%)$ & 8 & $(5.3 \%)$ \\
\hline 大学院生 · 研究生 ·学部生 (含学振研究員) & $400 \quad(12.5 \%)$ & 64 & $(42.7 \%)$ \\
\hline その他 & $345 \quad(10.8 \%)$ & 0 & \\
\hline 合計 & $3,193(100.0 \%)^{* *}$ & 150 & $(100.0 \%)$ \\
\hline
\end{tabular}

*会員は, 正会員, 学生会員, 名誉会員からなっている.

**丸めの誤差により合計は $100 \%$ にならない.

\section{4) 著者の職業構成}

学会誌の在り方は, 投稿者の側からだけでなく, 読者の側からみる必要もある。1999 年 3 月時点で の日本地理学会の会員 (正会員, 学生会員, 名誉 会員）の主な職業構成（いずれも非常勤を含む） をみると, 短大・高専も含む大学等教員 $33.4 \%$, 小・中・高校等教員 $23.2 \%$, 民間企業 - 官公庁等 勤務 $20.0 \%$, 大学院生・研究生・学部生 $12.5 \%$ と なっている $(\text { 表 } 6)^{12)}$ 。この会員＝読者の職業構 成比に掲載論文の著者のそれが対応していれば, ある程度読者のニーズを満たす誌面構成となって いると考えてよいだろう。そこで著者（連名の場 合は筆頭著者のみ）の職業構成をみると，短大・ 高専も含む大学等教員 $50 \%$, 大学院生 - 研究生 · 学部生 $42.7 \%$ となっており (表 6 参照), 大学で の研究・教育に関係する者が著者の殆どを占めて いることがわかる。前記以外の職層の掲載論文も 含め, つまりはアカデミックな地理学 (の最先端) の研究論文が誌面のほほ $100 \%$ を埋め尽くしてい ることが歴然としている。この誌面構成が，会員 の半数近くを占める学校地理教育の現場で働く人 たちや企業・官公庁で実務に携わる人たちのニー ズを満たしているという保証はない。

こうした反省に立ち，日本地理学会では，会員 構成に見合うように地理評を改組することを検討 しており，例えば年間 12 冊のうちの 1 冊を地理 教育関係の特集号にする案が浮上している ${ }^{13)}$ 。さ らには，実務に携わる会員に役立つものをという ことを考えると，学会役員へのアンケートでも指
摘されているように，新しい用語・概念や技法の わかりやすい解説記事を掲載する必要もあろう (日本地理学会企画専門委員会, 1993, p. 816)。 もちろん，そうした論文のジャンルを新たに設け るのでなく，それも特集号とすることが考えられ る。以上のことを，厳しい学会の財政状況の下， 年間 12 冊の中でやりくりするのであれば，それ 以外に研究・作業グループの成果を掲載する特集 号も年によってはあることから，通常号は年間 9〜10 冊刊行ということになる。自由投稿の枠は 減るが，その分より精選された論文が掲載される 可能性は高くなるであろう。いずれにしても，会 員が気軽に読み，気軽に投稿でき，しかも実用的 な論文を揭載する場を設けることを検討する時期 を迎えているようである。

\section{5）編集体制の在り方}

通常号年 12 冊を基本とする現在の発行体制が 変われば，編集体制も変わらざるをえない。現行 でも特集号は別に編集委員会が組織されているた め, 地理教育関係の特集号が毎年定期的に刊行さ れるようになると, その編集は地理教育専門委員 会が担当するはずである。編集体制の在り方につ いては, 現行でも問題がなくはない。例えば，委 員が学会事務所に月 1 回集まり, 合議制で論文審 査を行なうためには, 旅費のかかる遠方の会員に 委員をお願いできない。それでも無理を言って, 今期の編集専門委員会には関東以外の地方の会員 2 名も委員としてご協力いただいている。学会の 求心力の維持や, 関東地方の会員にだけ負担がか 
かる不公平さを考えれば，地方の会員にも委員を 務めていただくことを前向きに考えるべきではな いだろうか。

その場合, 余裕のない学会財政の下では, 現在 のように委員が全員集まる形の編集会議は開けな い。形としては, 審査結果を電子メイルで編集委 員長に集め, 委員長が原稿の採否を最終決定する ものとなろう。編集委員長の仕事は今以上に増え ると同時に, 権限と責任も大きくなるであろう。 さらに経費を節約するつもりならば，電子メイル による投稿を認め，ネット上での論文審査という 方向に向かわざるをえない。その際の選択肢の一 つが, 文部省学術情報センターが勧める「オンラ インジャーナル編集出版システム」の利用という ことになる。日本地理学会では年間予算支出額に 占める出版経費の割合がこの 10 年間ほぼ $30 \%$ 台

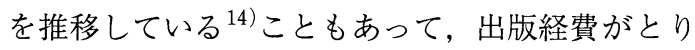
たてて問題になることはなかった。そんな事情も あり, 日本地理学会はネット上での論文審査や出 版処理について全く検討していない。また, 購読 者減につながることを危惧し, 文部省学術情報セ ンターの「電子図書館サービス」事業への参加も 見送っている（1995１997 年の試行運用には参加）。 学会事務体制の在り方, 印刷所との関係など微妙 な問題も少なからず関連しているが, 学会の財政 状況次第では地理評の電子出版の検討を始める日 は近いかもしれない。とはいえ, 面識のなかった 委員同士が知り合い, ときに大学院のゼミのよう な雲囲気で投稿原稿をめぐって議論し, 耳学問も できる，現行の編集会議も捨てがたいと思うのは， 私が 20 世紀型の編集委員長だからだろうか。

\section{V.むすび}

本稿では, 前半部分において査読システムも含 め地理評の投稿から発刊までの概略を述べた後, 後半部分において投稿・掲載状況からみた地理評 の問題々課題について, 現在編集に携わる者の立 場から考察してきた。その結果, 以下の諸点が明 らかとなった ${ }^{15)}$ 。

1）地理評への投稿数は必ずしも多いとはいえ ず, 月刊誌の宿命ゆえか, 常に手持ち原稿の
数を心配しつつ刊行している。

2）投稿原稿は完成度の高いものが少なく，そ の分，担当委員の負担は大きくなっている。

3）人文地理論文に比べ, 自然地理の論説の掲 載が少なく, 長期的には自然地理研究者の地 理評離れにつながる恐れがある。こうした状 況が生じている理由については, 両分野の投 稿先選択肢の多寡も関係していると思われる ので, 地理評と他誌との間での投稿先の使い 分けについて挆る必要があろう。

4）現行の地理評の誌面は日本地理学会の会員 構成を十分に反映しておらず，会員数を維持 するためにも, 地理評の改組を検討する時期 を迎えている。

5）関東地方在住委員中心の編集体制の在り方 についても, 全国の会員に均等に仕事を分担 してもらうという意味で, 検討の余地がある。 この問題は, 究極的には, 地理評の電子出版 の検討につながるものである。

以上の諸点は各々別個に存在するのではなく， とくに1)〜3）は相互に絡み合っている。すなわ ち, 投稿数の少なさは完成度の高い原稿が集まる 可能性を小さくし, 結果的に受理までの期間を長 くしてしまう。受理ないしは揭載までに時間がか かることを嫌う投稿者は，他誌へ投稿する。その 結果, 地理評への投稿がさらに減少するという悪 循環を招くことになる。最悪の事態は, 投稿数が 少なければ，毎月の刊行を維持するために審査の 基準を緩めて受理し, 雑誌の質を落としてしまう ことである。幸い地理評は現在のところこうした 悪循環には陥っていない。Science Citation Index (SCI) や Social Science Citation Index （SSCI）に類するものが作成されていない日本で は, 国内での地理評の引用度について容易に知る ことはできないが，1996１997 年の海外で刊行さ れた学術雑誌における地理評（Ser.Bを含む）揭 載論文の引用は 51 件 ${ }^{16)}$ と決して多くない。掲載 論文の引用件数が当該雑誌の評価を表わしている とするならば，地理評の紙価を高からしめるため にも, 地理学内外から多くの引用が期待される質 的に優れた内容の原稿の投稿を願ってやまない。 
注

1）地理評にかつては欧文論文が掲載されたこともあつ たが，1984 年に欧文機関誌（現英文機関誌）Geographical Review of Japan, Ser.Bが創刊されて 以後は, 和文論文のみ掲載している.

2）日本地理学会事務局内部資料による.

3）地理評に対する意見聴取は, 学会活動に関する学会 役員へのアンケートで試みられることがある（日本地 理学会企画専門委員会, 1993 ; 涉外専門委員会, 1995). また, 1988 年以降（1991 年を除く）の地理評 12 月号 揭載の「編集専門委員会から (のお知らせとお願い)」 において，毎年の投稿・掲載状況が報告されている.

4）1990年代初頭の研究・作業グループの活動状況に ついては，若林 (1991) を参照されたい.

5）以下の考察において使用した資料は，とくに断わら ない限り, 地理評と『日本地理学会会員名簿』(1997 年版）から得られるものばかりである。ただし，投稿 数, 審査原稿数, 受理原稿数に関する疑問点, ならび に学会消息では報告されていない却下原稿数について は, 日本地理学会事務局に本稿の主旨を話した上で問 い合わせ，回答をいただいた。

6) これ以外に, 討論論文 1 編があるが, 編集専門委員 会の不手際もあって掲載までに 3 年近くを要した。こ れは特異なケースであるので, 対象から外すことにし た。

7） 1991 年を除く, 1988 年以降の地理評 12 月号掲載の 「編集専門委員会から（のお知らせとお願い）」による.

8) 注 7 参照.

9) 注 7 参照.

10）原山（1996, p. 265）の第 1 表に示されている数字 を加工して用いている. 原資料は『日本地理学会会員 名簿』(1993 年版) 作成の際に会員に対して行なった アンケートから得られるが, 全ての会員が専門・関心 分野について答えているわけではない. なお, 自然地 理関連の 14 分野とは以下のものを指している. 地形 学, 第四紀学, 自然地理学全般, 環境地理学, 気候学, 水文学, 災害論, 水資源, 植生地理学, 氷雪地理学,
農業気象学, 生物地理学, 土畩地理学, 資源論.

11） $1996 \cdot 1997$ 年地理評 12 月号掲載の「編集専門委員 会から」による。

12）日本地理学会事務局内部資料による.

13） 1993 年時点の会員数（原山, 1996, pp. 263-264） と比べると, 1999 年 3 月時点では小・中・高校等教 員は 100 名以上減っている. それとは対照的に, 他の 職層は (微) 増加傾向にある.

14）日本地理学会事務局内部資料による.

15）本文中詳述しなかったこととして, 查読結果に対す る編集専門委員会への異議申し立ての問題がある. 投 稿者からのものは皆無に近いが, 外部査読者からは, 委員会での最終決定が査読結果と違う場合に, 異議が 申し立てられることがある. それに対しては, 最終決 定は委員会の合議によっていることを説明し, ご理解 を賜わっている。ちろん，どうしても決定結果を承 服しかねる場合, 誌上討論の道が残されていることは 言うまでもない.

16）日本地理学会事務局内部資料による.

\section{文献}

原山道子 (1996): 日本地理学会正会員の研究上の関心 についてー1993 年度実施のアンケート結果をもとに して一. 地理学評論, 69A, 263-276.

日本地理学会企画専門委員会 (1993): 「地理学の活性化 と日本地理学会の役割」についてのアンケート結果 (第 3 報). 地理学評論, $66 \mathrm{~A}, 816-820$.

渉外専門委員会 (1995): 渉外問題に関するアンケート 回答の集約についての報告. 地理学評論, $68 \mathrm{~A}, 278-$ 281.

立岡裕士 (1987): 戦前期の日本地理学会と『地理学評 論』一地理学の社会的制度化に対する貢献一. 地理学 評論, 60A, 516-539.

若林芳樹 (1991): 日本地理学会における研究・作業グ ループの現状と課題. 地理学評論, 64A, 408-414.

矢澤大二 (1975): 日本地理学会の研究活動 (年表解説 にかえて). 日本地理学会編 : 日本地理学会五十年史. 古今書院, 71-114. 